\title{
2
}

\section{Aesthetic Animals}

\section{A mythological history of animal exclusion}

Our attitudes towards animals may be traced to biblical imperatives, and the Hebraic creation myths - 'myths', in the plural, because two separate creation stories open Genesis: the 'seven day' and 'garden of Eden' myths. While they were written at different times, they are crudely juxtaposed in the text, as we know it. The seven-day creation story that opens the Old Testament is actually the later myth, dating from the 4th century BC, where the Eden myth was written between 930 and 721 BC (Fokkelman, 1987). These stories offer two different versions of human-animal relations. The later, seven-day creation story puts the human 'in command' of all other creatures, as crown of creation (reiterated in Psalms 8:4-8): 'God said, Let us make man ... let us put him in command of the fishes in the sea, and all that flies through the air, and the cattle, and the whole earth, and all the creeping things that move on the earth.... Increase and multiply and fill the earth, and make it yours; take command of the fishes in the sea, and all that flies through the air, and all the living things that move on the earth' (Genesis 1).

In Eden however woman and man walk and talk with the animals in equality. This idealized 'peaceable kingdom' is referred to in Isaiah 11:8, where the newly suckled child is able to play safely by 'the hole of the asp', and put its hand 'in the viper's den' without harm. Also, Yahweh is immanent in Eden, but wholly transcendent in the seven-day creation myth. These biblical creation myths, separated possibly by 500 years, offer then asting models of human-animal relations. The Eden myth is inclusive, describing human participation in animal life, or continuity amongst species, and an immanent Creator; the seven-day myth is exclusive, separating humans from animal life, and God from 
humans, describing a discontinuity of Creation, where humans dominate. It is this latter perspective that characterizes what James Hillman (1989c, p. 95) calls 'our Western tradition's contempt' for 'the animal soul'.

In a discussion of 'nature' and the 'natural', Jung (1976) refers to the Oxyrhynchus papyri, discovered in the Nile Valley in the early part of this century, which include early copies of the New Testament and apocryphal books such as the Gospel of Thomas. There is a particular papyrus, which Jung claims was not admitted into the New Testament by the early Church Fathers, despite being older than the Gospels, and equally authentic to them as a record of Christ's original teachings. The text of this papyrus records a supposed conversation between Jesus and the disciples in which they ask him how one is actually transported to the Kingdom of Heaven. Jesus replies: "The fowls of the air and all beasts that are upon the earth or under the earth, and the fishes in the sea, these are they that will draw you into the Kingdom"' (ibid., p. 284). Remarkably, this is close to the typical teaching of an animal-centred or animal-directed shamanism, where the animal is the vehicle of illumination, the deity to whose realm the human is drawn and must aspire, and from this animal humans are said to be descended. Such contact with the animal god recreates the original continuity between species in Creation, returning us to Eden, among the animals, not separated from them.

Given that we carry contradictory creation myths in the collective psyche it is not difficult to understand why our modern attitudes to animals may be confused: that we love them and fear them; that we make pets of them and torture them; that we see ourselves as part of the animal kingdom and as separate from it and master over it. Since the rise of a rationalist and humanist modernism, with its announcement of the death of God and scepticism towards ancient myth (replaced by the modern myth of science), one would think that biblical imperatives held little sway. However, as any good Jungian will inform us, we cannot so readily sweep away our collective history and its mythological soil.

Animals already come with cultural tickets attached. They are signifiers - they carry meaning beyond their biological self-presentation and such meanings can be said to have been established upon some very simple structural principles. To remain with our biblical framework, recall that Yahweh saves all the species of animals through instructions to Noah to house them in the Ark. This seems like a fitting ecological metaphor, but it has been argued that the myth encodes a social regulation. The choice of animals by Noah is based not upon how animals appear, but upon what they represent for the human. Animals here are 
treated as signs in a system, their meanings derived not from aesthetic self-display or presentation, but from representation, where the animal stands for something other than itself. While - in Genesis 7 - Yahweh appears to favour the entire animal kingdom in saving them, as all may enter the Ark, this is however subject to certain conditions where some animals are privileged over others: 'Take seven pairs of all the clean animals ... and two pairs of all the animals that are unclean'. The basis for such classification and taboo is offered in Leviticus 11 and, from the perspective of a structuralist analysis, reveals a human use of the biological world to erect a cultural sign system.

The Levitican order offers a shorter list of so-called 'clean' animals such as cattle, and fish with fins and scales and a longer list of tabooed or 'unclean' animals such as camel, sow, chameleon, cormorant, and fish without fins and scales. According to Mary Douglas (in Baker, 1993, p. 111) the basis to such a classification system is that the 'clean' animals are those which chew the cud and have cloven hooves, and do not crawl on their bellies. Thus, the camel chews its cud but has an uncloven hoof. The sow has cloven hooves but does not chew its cud. Also, a taboo applies on the basis of whether or not animals are perceived as either whole or composite, as a basis to whether or not they are, respectively, holy or unholy (as 'pure' or 'impure'). The animal is then used as a metaphor for a reflexive understanding of a principle supposedly operating throughout the natural world. What is unholy, unclean and to be tabooed (which also means to be feared and avoided) is what crosses borders, is a hybrid or does not easily fit a category system. This would allow us to read the taboos in a variety of ways - for example, animals which are seen to be lacking something or are incomplete (fish without fins or scales), transform (chameleon), or inhabit two environments (cormorant) are to be tabooed, for they cross boundaries, or offer mixed messages, upsetting an imposed order of 'purity'.

The classification reveals a hidden principle: intolerance of ambiguity. The same principle essentially pervades the purist strain of Modernism, that resists hybridization and transgression, and indeed has been identified as a consistent feature of the 'Authoritarian Personality' (Adorno et al., 1950), that itself is seen as the individual basis to fascism. In the Levitican order the animal becomes a vehicle for expression of a cultural order through a logic based on the privileging of a naive purity over ambiguity on the basis of selected characteristics. The animal is then deprived of its total and complex presence as it is viewed through human dogma not for what it presents (its self display), but, again, only for what it represents (its value as sign in a human code system, relative to other signs). 
If we follow Bruno Latour's (1993) probing analysis, modernism can be characterized as a misconceived project for promotion of purity over the ambiguous and the paradoxical. In this analysis, Modernism is characterized by intolerance of the hybrid, where it uses the tools of oppositionalism and rigid classification to maintain conceptual boundaries between phenomena that are experienced in reality as complex hybrids. The quintessential opposition is between nature and culture; others include body and mind, science and art, male and female. But these purist divisions, so easily held as concepts, collapse in practice, which tends to hybridization, in-betweens, admixtures, compounds and complexities. Further, the more a conceptual purity is sought, the stronger is the return of the repressed hybrid, crossing boundaries and dissolving classifications. The notion of a civilized culture depends upon the maintenance of a strong boundary between nature and culture, animal and human. But the more we insist upon this boundary, following the hierarchical seven-day creation myth, the more the repressed nonhierarchical, plural and inclusive Garden of Eden myth will return, and return in a distorted form, poisoning the attempted purity of the humananimal opposition.

\section{The return of the repressed animal}

A contentious scenario for the return of the repressed animal is that one of the possible sources for HIV-1, a major strain of the AIDS virus, is the green monkey of central Africa, which may have attacked, scratched and infected workers on forest clearance schemes. Naturally, if we slash back the habitat of these monkeys, they may fight back. One strain of AIDS may then be an indirect result of deforestation involving an unwanted incursion into an animal's habitat. Does the British BSE scare discussed in the previous chapter also reflect the return of the repressed animal? Again, as Freud suggested, the repressed invariably returns in a distorted form.

As a less contentious scenario let us imagine that the silence or incomprehensibility of madness, as the unknown 'other', excluded on grounds of purity, forced modernist rationalists to invent the fictional land of the unconscious in order to explain away madness and avoid contamination by the irrational (for the so-called 'unconscious' neatly parcels the irrational in a conceptual apparatus). By the same token could we not suggest that the silence or incomprehensibility of the animals has forced the same modernist rationalists to invent the psychological concept of 'instinct' to explain away the animal in us, or to provide a neat 
conceptual cage for our animality? The repressed animal then also returns in distorted, inflated concepts - not only in symptoms of body, but also of mind. Let us track this animal, knowing that it will surprise us nevertheless.

In Civilization and its Discontents Freud (1930/1994, p. 24) describes a civilized country as one in which 'wild and dangerous animals have been exterminated'. In this phrase, recalling that this is the writing of the later Freud, he is also describing his own conservative views of the civilizing or socializing of the natural psyche. It may be true to say that the more civilized the society the worse are its attitudes towards animals (Green, 1992). While one of the moral precepts of the ancient Greek mysteries at Eleusis was to not be cruel to animals, this tradition has been superseded by a rationalist outlook that may be traced to Aristotle's influence.

Aristotle (in Clarke and Linzey, 1990, p. 6) suggested that humans are superior to animals because humans possess rational intelligence, where animals have 'limited' souls. Further, animals are not 'political' - they have no sense of justice; and have no obvious morality, no 'perception of good and evil, of just and unjust'. Indeed, Aristotle says that animals are put on earth for human use, and that this could not be seen as an injustice because animals themselves are incapable of defining justice!

Aquinas (Summa Theologica Q.XCVI) follows Aristotelian orthodoxy, suggesting that we can have no true intimacy with animals because they are irrational. Animals, according to Aquinas, are God-given for human use, and hence it is not sinful to kill them: 'it is in keeping with the order of nature, that man should be master over animals', and, 'man, being made in the image of God, is above other animals' (in Clarke and Linzey, 1990, p. 7). Stephen Clark (1994, p. 24) suggests that 'Aristotle, the Stoics and the Epicureans all agreed that "animals" ... were not reasoning beings'. Augustine (in Clarke and Linzey, 1990, p. 60) concurs with this bias, where 'the irrational animals that fly, swim, walk, or creep ... are dissociated from us by their want of reason, and are therefore by the just appointment of the Creator subjected to us to kill or keep alive for our own uses'.

Rationalism in western thought has contributed four major approaches to denigration of the animal. First, Aristotle denies animals souls where he ascribes fullness of soul only to humans. Second, the Roman world and Augustinian Christianity, following Aristotle, makes animals our property and slaves, to use as we please. Third, the Cartesian outlook ascribes lack of feeling to animals and turns them from slave into soulless machine, prefiguring factory farming. Fourth, while restoring the 
human to the animal kingdom against biblical orthodoxy, Darwinism nevertheless places the human at the apex of animal life arranged as a hierarchy of neurological complexity.

John Berger claims that contemporary human-animal relations are characterized by an absence of contact, epitomized in the nature of the gaze - where the fact that animals may gaze upon us is lost to the nature of our gaze upon them. Our gaze objectifies the animal, constructing it as imperfect 'other', as lacking. Such a relationship is a suffering one, where a meaningful contact with the animal is lost or deferred. Berger's suggestion is that an authentic relationship to animal life has been corrupted by capitalist enterprise, where animals have come to be seen as a walking larder, a convenient food supply to be exploited on behalf of humans. In recent times, animals have become used more and more in scientific experimentation in the name of human progress, reducing the animal to object. We have moved, suggests Berger, from living with animals to living without them, and this is especially true of the urban majority. Clark (1994, p. 24) summarizes this position as 'our present inattention to the interests of the non-human'.

Robert Stein (1984, p. 7) suggests that we have traded our 'animalinstinctual' natures for a culture of mechanization, and that the 'return' of the instinctual human 'cannot occur without the help of the animals themselves'. Stein reminds us that a fairy tale motif involves the redemption of the hero through 'trusting or befriending a dangerous, repulsive or apparently insignificant animal'. As we encounter the animalinstinctual nature of ourselves, which Stein simply calls 'the animal', so we find it hard to familiarize ourselves with what may be 'sick, misshapen, vicious and perhaps monstrous'. For Gary Kowalski (1991, p. 95), the presence or absence of animal life in relation to the meaning of human existence constitutes a theological issue, where he asks: 'would we lose our own souls in a world without animals?' Human experience, in these views, is impoverished without regard to the presence of animals. If entry into 'Heaven', as Jung's reference to the lost Gospels would indicate, is dependent upon the animal vehicle, then surely full participation in life on earth is even more dependent upon our recognition of the value of the animal. While these accounts are highly empathic towards animal presence, they nevertheless imply rather than intend the animal as they lean heavily towards human interests and human psychology, and then deny the animal as wholly other, as autonomous.

In a critique of Jung's tendency to psychologize animal life, or reduce the biological animal to anthropological terms such as 'instinct', Michael Whan (1994), as indicated in the previous chapter, ventures that the 
animals themselves may bring 'meaning' to this world. To pursue this line of imagining further, in such an animal-human relationship the human is not denied autonomy but gains through the heteronomy of the relationship to a familiar animal presence in a recognition of 'difference'. The human is then, to return to our earlier discussion of Dante's descent to Hell, pushed deeper by animal presence, or denied a return to the safety of the mountain (the moral, practical and intellectual 'high ground' of assumed human superiority). Further, to borrow from, and adapt, Emmanuel Levinas's view of human-to-human heteronomy, the person remains, appropriately, 'hostage' to the ethical implications of the presence of the other - where, in this case, the animal familiar is both wholly, and holy, Other.

\section{The return of the repressed human to an animal commonwealth}

A North American Indian teaching story offers the following paradox: you stumble across an animal caught in a trap. Your first response is one of pity, a desire to release the animal. On closer investigation however, you see that the animal in pain may also be savage and vicious. If you release it from the trap, it may attack you rather than display gratitude. What should you do, as your feelings sway between compassion and fear?

As you contemplate this paradox further, you may come to realize that the 'trap' is not that in which the animal is caught, but the opposition created between you and the animal. A further paradox is that this opposition is not your invention - rather, you find yourself situated in it, as an aspect of cultural discourse. What if the animal in the trap is you, or rather the cultural discourse in which you find yourself trapped? Further, in releasing your own or the culture's wild or savage animality (the repressed), will it attack you? Or should you leave it as it is, trapped and pained?

We are now so accustomed to Freud's famous assertion in Civilization and its Discontents - that culture originates in the repression of desire, of the instincts of unbounded sexuality and aggression - that we have perhaps become anaesthetized to his radical insight. Let us again consider Freud's notion: cultural advancement is bought at a price. The instinctual or animal body that is polymorphous perverse sexually and - potentially - unpredictably violent, is cultured or tamed primarily through the ego defence mechanisms of sublimation and displacement. Freud came to see this as a necessary discontent - without it, civilization 
would not be possible. To repeat and enlarge on an earlier quote, according to Freud (1930/1994, p. 24), a country that 'has attained a high level of civilization' is one in which, among other characteristics, 'wild and dangerous animals have been exterminated', and 'the breeding of tamed and domesticated ones prospers'.

Recall that the wild and adventurous young Freud, love-struck, and passionate advocate of the use of cocaine as a prophylactic, gave way to the conservative patriarch who claimed to have given up sex in middle age in order to study it rather than enjoy it. When André Breton, the founder of Surrealism, finally gained a personal interview with his hero Freud, Breton apparently came away severely disillusioned. Freud reputedly said that what Breton stood for - the artistic representation of untrammelled desire or the direct articulation of unconscious life - he himself saw as dangerous, for such desire must be socialized, with a view to developing a healthy ego rather than living the experimental life guided by id or animal sense.

If we return to Freud's original insight in Civilization and its Discontents, what if we were to develop that radical view more fully, as the Surrealists had hoped to do? What if we were to privilege the animal body, the instincts, desire, rather than culture, reversing the orthodox western view that the animal, in relation to the human, represents lack? What if human culture were seen to be lacking in relation to the potential riches of the non-mediated biological life, that Jacques Lacan describes as the order of the real, outlined in the Introduction? Could it be that Freud turned his back on his own insight because it is unbearably convincing and historically accurate - that the animal is prior to the human? More specifically, the animal constitutes an a priori condition.

As Jean Baudrillard (1994, p. 133) suggests: 'Once animals had a more sacred, more divine character than men.... and for a long time the animal order has been the order of reference.' If we are to restore the radical effect of Freud's insight, then we have to reverse the view that the animal offers lack in relation to human. Rather, we would see human cultural 'advance' (sublimation, mediation, interpretation, representation - Lacan's order of the symbolic) as offering lack in relation to the powerful immediacy of the biological (aesthetic self presentation the order of the real); the cultural then destined to always be plagued by fantasies of the biological.

Nietzsche (in Norris, 1985, p. 8) offers a similar view in a different key, as an anti-anthropocentric sentiment that is worth quoting at length: 'Once upon a time, upon a star in some remote corner of the universe glittering and bestrewn with innumerable solar systems, clever 
animals invented knowledge. It was the most arrogant and untruthful moment in the "history of the world"; but it lasted only a minute. Nature had just taken a few breaths when the star petrified, and the clever animals died. One could invent such a fable and still not illustrate how purposeless and arbitrary the human intellect appears in the context of nature. For eternities it did not exist; and when it is once more extinct, nothing will have changed. For this intellect has no broader mission that would extend beyond human life. It is human, only, and only its possessor and inventor treat it as seriously as if the axis of the world revolved inside it. But if we could communicate with the mosquito, we would discover that it sails through the air with the same empathy and feels itself the flying centre of the world.'

Scratch the surface of any pre-industrial hunter-gatherer culture and you will find the same anti-anthropocentric sentiment (or, in this context, pre-anthropocentric). Indeed, in such cultures, the animal is often privileged as 'centre of the world', where animals provide reference for human culture as deities. Or, in such cultures, animal and human are identified, where the animal is not anthropomorphized, or appropriated by humans - as with our pet culture, or the typical TV wildlife experience - but humans are seen as aberrant examples of the totemic animal, from whom the people in question are descended. When the Amazon Basin Bororo say they 'are' Macaws, or the Uduk of the Sudan see themselves as brothers and sisters of the antelope, while we will not, as good Cartesian rationalists, take them literally, we must take them seriously. We cannot simply dismiss such identification as regressive (pre-logical, innocent, childish), a psychological projection, or a linguistic trick. This identification between human and animal is a way of saying that the animal is prior to human, provides reference, is deity, and must be seen as providing the vehicle for an affectivity that precludes divorce between the species.

Wolfgang Giegerich $(1989$, p. 1) suggests that the lack rationalist western culture ascribes to animals could be read rather as a displacement of our impoverished relationship to them, or loss of familiarity, especially for the growing urban population. Our actual contact with animals today, suggests Giegerich, is one of absence: 'the very meaning of animal today is one of the following: 1) extinct, 2) endangered species, 3) tourist attraction in zoo or reserve, 4) pet, 5) milk or meat producing machine within a highly industrialised farming enterprise, 6) guinea-pig for laboratory experiments, 7) biological organism and production of evolution'.

Adding to this pessimistic list, we could also consider that (8) for many people certain animals are often only encountered squashed dead 
on motorways; or (9) adapted to urban environments, usually raiding rubbish bins; (10) encountered whole or part in freezer cabinets of supermarkets (the animal, such as a whole frozen trout, first encountered in vivid photographic detail in the wild on the container or wrapping - a photograph which is in fact a montage based on how we imagine, idealistically, the animal to be in the wild, free and healthy, and hence a perfect example of a simulacrum, a copy without an original); (11) as infestations, such as head or pubic lice; (12) in hyper-reality on TV wildlife programmes (where we see animals as we never would in the wild, with close-ups, dramatic cut-aways, intense action, in brilliant colour, with exciting commentary larded with anthropomorphic metaphors of sex, violence and domestic life, thus providing a vibrant simulation, but often reducing animal life to the status of human soap opera).

Such televisual experiences are, of course, entirely optical and auditory, thus devoid of the so-called 'lower' animal senses of taste, touch and smell. The representation of animals in this way contributes to a post-modern, post-industrial culture seduced by hyper-reality and simulation of experience as a normative event (Baudrillard, 1994; Bogard, 1996). Thus, bestiality would represent the intolerable, as a principle of unmediated experience and hence of uncertainty, and such bestiality must be killed. Most importantly, it must be killed in the beasts themselves. Animals must be tamed, or represented through simulation and the simulacrum.

If our animality were let loose, if the animal were to be freed from the trap, by Freud's law of the return of the repressed it would necessarily act in a distorted fashion. However, what if we invite the animal back into our lives, a brazen return through the front rather than side door? Then we may find that the animal brings a gift of both the beautiful and the sublime. Our model could be the seahorse, who in the wild demonstrates a life of the aesthetic, of elegant self-display; who shows tenderness, wrapping a tail gently around the finger of prying zoologists just as the male and female seahorses go for walks with their tails entwined; who shows fidelity - a mate for life; and who throws the assumptions we make about gender in animal life into disarray, for it is the male seahorse who incubates the ova that the female injects into his birth pouch, and who eventually gives birth. Perhaps what frightens us about animals - just as it simultaneously intrigues us - is not their irrationality, their bestiality, their primitiveness, but the depth, the sublimity, the sheer range and unpredictability of their aesthetic self-display.

While reading animals conceptually - as signs within a human system of meaning - deflects us from appreciation of their value in immediacy 
of self-presentation, the aesthetic appreciation itself is blocked by our tendency to instrumentalism or to functional readings and explanations. How, for example, does a functional view in any way encompass the bizarre case of deep-sea organisms that give off eerie, coloured light, a kind of fluorescence, when other organisms in the same environment do not possess the optical structures necessary to see such light, yet humans do? It is as if these organisms had waited thousands of years for the invention of the bathysphere so that we could witness their display in its full glory! Their display offers us pleasure, and - where we have not appropriated these animals - so they generously intend us.

For some animals, of course, their beauty does not rest with a gentle aesthetic display, but with one of power and aggression such as the lioness running down the antelope, the pinch and grip of the crab, the sucking and entwining octopus. For these animals, docility, lethargy and feebleness would constitute a distortion, and this of course is how we see the return of the repressed in such animals when they are exhibited in the zoo or the circus for our entertainment.

Some contemporary scientists - notably Brian Goodwin (1995) and Stuart Kauffman (1995) - suggest that life is a self-organizing aesthetic system. Life is efflorescent, and has purpose in the sense that it wants to display or show. This is now termed the 'emergent properties' of systems, expressing a complexity in life forms that is best described in terms of process rather than content, and as maximum complexity at the edge of chaos. While systems tend to entropy and chaos, they are also capable of re-ordering at new levels of complexity, demonstrating emergent properties. Zoologists such as Adolf Portmann (1982; 1986) have also described animal life not through the tired anthropocentric, instrumental metaphors of war (camouflage, the fight for survival, territorialism, and so forth), but through the language of aesthetic self-expression and sublime presence. Portmann for example points to the 'functionless' aspect of much animal display as ornamental, as not serving functions such as delineating a territory or attracting a sexual partner. He notes for example that the singing of birds is largely a creative use of free time. (Even when our intentions are good, it is difficult to adequately describe such behaviour without resorting to the human metaphors of the leisure and tourism industries.) 'Nothing useful!' in these displays exhorts Portmann (1982, p. 33). Rather, they constitute a deep expression of form.

In order to satisfy the call for what Roy Willis (1994) has termed 'Humanity's reincorporation in the natural Commonwealth' we must shift from person-centredness to animal-centredness, and further, to animaldirectedness, learning from the beasts. It is the animals themselves who 
will surely lead us to reformulate the ecological crisis, as we respond to their intentions, for the animals already show that they do not want an an-aesthetic life, a life of numbing, insensitivity, a half-life. Rather they will awaken us through their sensitivities, their aesthetic presence, to our self-imposed numbness to the world.

A cursory study of extant - and where records allow, extinct - huntergatherer cultures reveals a commonality: their religious life is centred on animal presence. The functionary who maintains contact with the world of animals in the literal and dream worlds (which are recognized as continuous, and not opposed or disjunctive) is the shaman, who primarily journeys in ecstatic trance to an otherworld of animal spirits to apologize to the spirits of animals killed in the hunt, and to check that the hunt taboos are not broken. Such small-scale societies demonstrate identity and familiarity with certain totemic animals and claim descent from them. They stress continuity with the world at large, rather than the discontinuity between person and environment described by modernist industrialized and post-industrial cultures.

There is evidence from anthropology (Maybury-Lewis, 1992) to demonstrate that totemic, shamanic, tribal cultures also tend to lay stress upon what is hidden or covert in the world (such as an unseen, but felt spirit realm), rather than what is explicit or explicable. Such cultures are interested in conservation, equilibrium and continuity rather than change; and often see the world as a hostile place in which suffering is accepted and expected, so that people are charged with an anxiety motivating regular appeasement of spirits (in spite of the tendency for New Age pundits to idealize such cultures as peaceful, non-neurotic and optimistic). Indeed, the familiar animal, the totem, is expected to be both an educator/initiator and an aw(e)ful presence, both edifying and terrifying. Further, the 'animal' denotes not only the literal, biological animal, but also the spirit and dream animal, so that animals are apprehended psychologically rather than either perceptually or conceptually. Thus, for example, a Greenland Inuit shaman reports that he was initiated through being eaten by a huge polar bear: 'It attacked me and crunched me up, limb by limb, joint by joint, but strangely enough it didn't hurt at all; it was only when it bit me in the heart then it did hurt.' And the shaman was regurgitated, stronger and wiser (in Halifax, 1980 , p. 109). Note that it is the animal that incorporates the shaman, so that the shaman 'inhabits' the bear and not vice-versa (which would be to appropriate and humanize the animal).

Joan Halifax (1982, p. 6) calls this animal-centredness and animaldirectedness characteristic of small-scale or tribal cultures a 'cathexis to 
the realm of creatures'. Gisli Palsson (1994) gives a telling account from a study of the history of fishing in Icelandic villages that illustrates such a cathexis and its modern dissolution or displacement. Prior to the modern industrialization and commercialization of fishing, the village fishermen would say that the only reason they had success in the catch was because of their own 'fishness'. This gave them empathy with the catch and allowed them to appreciate the role of the water spirits in regulating how many fish could be caught, as a natural conservation. Today however fish and human are separated and there is no compassion for the catch, which is mediated by industrial process and commercial demands, leading to a danger of fishing-out the shoals. Palsson describes this shift as one from pre-modern hunters informed by 'fishness' to modern hunters informed by 'technology'. This would describe a dramatic shift of values - from animal-directedness to person-centredness and beyond, to economic-directedness, the god Mammon displacing the traditional fish-god.

\section{Three kinds of animal presence (and many unaccounted absences)}

We are constantly reminded by biologists of the significance of Darwin (and Wallace) returning us to incorporation into the animal world. Since Darwin, we now know that we share over 90 per cent of our genetic material with our closest relatives such as the chimpanzee. However, our brain capacity has doubled in just two million years, an extraordinary evolutionary leap leading to a unique scenario - the capacity for complex language use, reflection, and prediction. The cultural outcome of this is the human subject becoming an object of its own study.

The human, while an animal, can then perhaps only know the biological in a highly mediated sense - the point made by Lacan in his insistence that the human is trapped in the culturally-enhanced imaginary (pre-verbal) and symbolic (verbal) registers of language, and then forever insulated from the register of the real, the now unknowable biological realm. This is registered as a lack, and promotes desire. The poet Clayton Eshleman (1983) suggests that such a mediation - a significant break from the biological, that he calls a 'therio-expulsion' - can be read from the evidence of Palaeolithic cave art from over 20000 years ago. Eshleman sees the animals portrayed in such art not as naturalistic representations at all, but as images of animals seen in human dreams. If the human cannot be fully biological, can the mediation of the biological through the realm of the imaginary, rather than the symbolic, 
offer a unique form of animal existence for the human - an animality of the human psyche that does not suffer from the absolute severance from animal life of the symbolic realm? Such an animality would constitute a form of imagination in which the animal is neither reduced to instinct (as a misconceived attempt to recover the realm of the real, or 'Nature'), nor wholly enslaved as linguistic tropes, as signs, symbols or allegories.

What are our models of 'animal life' that would lead us to see the animal as significant for human existence? What do we mean by the 'animal'? Let us return to our distinction between the three kinds of animal presence. The biological animal is the 'taken for granted' beast, treated in a literalist or essentialist manner. Ironically, this animal is also subject to reduction to its anatomy and physiology. Indeed, its genetic make-up or 'map' has become the primary biological signifier. Contemporary sociobiology has reduced us to the naked gene, where we are merely vehicles for the continuity of our 'selfish' gene pool. The biological animal is thus imagined literally, materially, and functionally or mechanically, and then reductively. But, as we suggest above, the biological animal can also be apprehended aesthetically. Laboratory zoology, and physiology and biochemistry have eroded the macro-perspective of natural history, where the animal is studied in the context of its habitat. Further, as has been said, watching animals in the wild has been displaced by watching virtual animals on TV 'wildlife' programmes.

Second, is the animal of the mind, or animals utilized as signs in language or symbols in a system or code. Here, the animal is also troped, as figure of speech, such as a metaphor ('a beastly situation'), simile ('as sly as a fox'), or allegory ('Wind in the Willows', 'Brer Rabbit', 'Animal Farm'). Or the animal is utilized semiotically as with the naming of sports teams ('Toronto Blue Jays', 'Chicago Bears') or cars ('Jaguar', 'Beetle'). Or the animal is utilized symbolically (the bear representing strength; the peacock, vanity). Or, as in Lévi-Strauss's structuralism, discussed in Chapter 5, biological animals, through their relations to each other, come to offer models of structural relations that the human may internalize as rules of representation (for example, eagle is to snake as air is to earth). The animal of the mind is an animal of social construction rather than an essentialist animal. Its presence is not defined by what constitutes it from within its own nature (identity), but how it is construed as an element in human culture. This returns us to our earlier discussion of a structuralist reading of the Levitican animals as a code for human conduct and rules of purity and contamination, inclusion and exclusion, singularity and hybridity. Here, the biological animal is imagined conceptually, or semiotically. 
Third, between the biological and the mental, between animals in body and animals in mind, is the psychological animal, the animal experienced as image (or, the image generating the experience of 'animal'). This animal is neither 'real' in the biological sense, nor 'abstract' in the cognitive sense, but participates in both the physical and non physical worlds. The animal appears in the psychological realm - or habitat of the personal and cultural psyche or imagination - as an image that is tangible and sensual and cannot be reduced to the realm of ideas, but is also not literal or concrete. The animal here is neither essentialist (has a closed identity), nor constructed (is an element in a human social system), but presents a separate discourse of animality that cannot be reduced to the biological or the conceptual. This animal is ontologically real, but it is neither just matter (literal), nor just an idea (construct). Rather, the psychological animal offers an aesthetic discourse as a language of images grounded in self-display. The location of this psychological animal offers a paradox. It is interstitial and most at home in the dream, and appears as the spirit or familiar animal common to the religious contexts of small-scale societies, including the animal-centred shamanisms that linger as elements of rural religious and folklore practices even in post-industrial countries such as Japan (Blacker, 1986).

Gaston Bachelard - drawing inspiration from the work of the protoSurrealist Isidore Ducasse (whose work is described in Chapter 4) - has provided a caring and careful phenomenology of the psychological animal, while articulating the very nature of its appearance to consciousness, its presencing, as a species of the imagination. For Bachelard (1986, p. 27), 'A need to animalize ... is at the origins of imagination. The first function of imagination is to create animal forms.' This would make the animalizing imagination pre-presentational rather than representational. For James Hillman (1981, p. 49), who, following Bachelard, has done more than anybody within post-Jungian psychology to establish animalizing as a primary type of imagination, the issue is how we might 'Restore the animal sense to imagining.' Prefiguring such views, the great Modernist poet of the darker passions, Rimbaud (1932, p. 37), suggested that 'The poet is charged with humanity, even with animals', which Edith Sitwell (ibid.), in a commentary upon Rimbaud, takes to mean, 'that the poet bears the life of all humanity, of all animals, within his soul'. Sitwell, after Rimbaud, is then suggesting that care of animal life, the nurturing of animal presence, is not primarily the task of zoologists and naturalists, who study animals. Rather, it is the task of 'poets'. Let us take this to include those who, following a shamanic tradition, would not baulk at the notion that (to paraphrase Nietzsche's Zarathustra) the 
beasts may guide us, and that certain animal presences, as familiars, may offer a particular type of education. If it is the task of poets, rather than (or as well as) naturalists, to track these beasts, then we also need to track the apprehensions of these 'literary beasts', who write as the animal, not just about the animal. This is our task in the following chapter.

The animalizing imagination should not be seen primarily as the psyche interiorized in the human, but constitutes an apprehension in which the interiority of the world at large is appreciated. In his 1928 essay 'The Structure of the Psyche', Jung (1969, p. 155) says, 'I once experienced a violent earthquake, and my first, immediate feeling was that I no longer stood on the solid and familiar earth, but on the skin of a gigantic animal that was heaving under my feet'. This image of the world as a living animal is characteristic of shamanic and neo-shamanic views, from Turtle Island to Gaia. Plato - in Timaeus - also describes the Earth as a living animal. In primal cultures that appreciate the world as animal presence dreaming us into being, there is the conviction that the kind of image Jung describes is not a projection; it does not have its origin in the person, as response to the world, but has its source in an animated world which dreams the person, educating us into its presence.

\section{Intestinal fever}

Let us move into a quasi-case study, as a celebration of the aesthetic animalizing imagination and the biocentric attitude introduced above. The case in question is the lowly pig - and our pig-nature. The choice of pig is to some extent arbitrary - the animalizing imagination would weave a story through the medium of any animal form. However, the pig does get a raw deal from humanity - it is one of the animals regularly receiving strong projections of bestiality. Yet the pig is drawn close to humanity in our association with it through domestication; in its innards so closely resembling those of the human; and in its appointment as the first possible animal heart donor for human transplant. To restore a celebratory vision of the pig we need to recall on the one hand the particular aesthetic of the animal embedded in the rich secular vocabulary of 'porklore': the tropes of the hog. And on the other hand, the sacred status of the animal exemplified by reverence for the sow goddess and boar god such as the Scandinavian Freyja and Frey; through the boar cults of the Celts (the tusked boar as the fearsome warrior, the sow as fecund); and through reverence for the sow sacred to the Egyptian goddess Nut, and the Greek Mother and Daughter pair Demeter and Persephone. Typical of reverence for the pig in Celtic lore is the Welsh 
story of the hero Culhwch, from The Mabinogion cycle of stories. Culhwch is the arch-hero who quests for a bride (Olwen) and has to undergo a cycle of initiatory experiences. As with all hero cycles, the boy-man attempts to escape the binds of the Mother as he is paradoxically and inevitably drawn back into her powers. The hero in this tale has a sow for a mother, for 'Culhwch' means 'found in a sow's vagina', or 'born of a sow', and this is what the myth tells (Layard, 1975, p. 7). In Celtic myth, human and pig are often interchangeable, and the pig is often referred to as immortal (Green, 1992, pp. 170-1).

Domesticated possibly by $3500 \mathrm{BC}$, the pig was already revered much earlier. For example, goddess figures wearing pig masks, and images of pigs themselves, have been excavated in Eastern Europe, dating from the middle of the fifth millennium BC. Some of these figures have been impressed with grain, leading to speculation that the pig was associated with a fertility cult in which the fattening ears of corn and the fattening body of the pig were identified (Campbell, 1988, pp. 58-9). Frazer, in The Golden Bough suggests that Demeter and Persephone were anthropomorphized versions of earlier sow divinities, and describes the sacrifice of pigs to the underworld in the Women's festival of the Thesmophoria. The required sacred meal of pork offered a communion, the participants feasting on the body of the goddess.

There is a large literature on the sacred pig, an animal that has been important to the economies and mythologies in particular of SouthEast Asia, the Pacific Ocean islands, West Africa, Europe, and the South-East areas of North America. Central to such mythologies is the triangle: pig (sow) - woman - moon: 'There is much coming together of "pig" and "moon" in primitive pig mythology' observes John Layard (1975, p. 51), who sees such mythology as characterizing 'the world of femininity'. Rather than reduce this to vague associations with 'fertility', it would seem that the pig, its sacrifice, and consumption of its blood and flesh are tied more directly to menstruation and the magical power of a woman's menstrual blood. Jane Harrison (1962, pp. 152-3) says that ancient Greek religious festivals required purification rituals prior to participation in the rites, and that these might include animal sacrifice and eating the flesh of the animal god. The animal also offered the vehicle for sacrifice, as a pharmakon, the poison that heals, or the god replete with taboos (the simultaneously dangerous and beneficent god). One such purification ritual involved driving a young pig overland to the sea and ritually bathing with the pig, who became the accompanying god of purification. The pig may then later be sacrificed. 
In C.E. Evans' (1987, p. 140) study of 'the lost history of Europe's animal trials' is the case of a sow, in France in 1386, 'sentenced ... to be mangled and maimed in the head and forelegs, and then to be hanged, for having torn the face and arms of a child and thus caused its death...the sow was dressed in man's clothes and executed on the public square'. Swinish behaviour; swinish amusement? While we may be horrified by such accounts, at least here the animal is being treated as a significant Other to be accounted for, and not discounted.

The pig's body is a god's body, not only significant other, but sacred Other. That the eating of pig flesh is tabooed in Leviticus is a sure sign of their status as gods. Pigs traditionally bring divine gifts: they are said to see the wind and we too can obtain this second sight if we 'Suck a blue sow' or 'drink a sow's milk'. We could describe this as going the whole hog, happy as a pig in shit. And while the pig is unfavourably associated with dirt and waste, there is nothing wasted in its gift of sustenance to the human consumer, where 'nothing but the squeal escapes the butcher' (Clark, 1968, p. 17).

In the final vignette of Quentin Tarantino's (1994) 'Pulp Fiction' the hoods Vincent and Jules have just shot three men in cold blood and splattered the brains of another across the upholstery of a car interior. They are sitting in a diner, Vincent greedily forking a stack of pancakes with sausages washed down by coffee. In contrast, Jules pushes around a single muffin. They are discussing the merits of pork. Vincent offers Jules a sausage, Jules refuses: 'I ... don't dig on swine' because 'They're filthy animals. I don't eat filthy animals.' But, says Vincent with relish: 'Bacon tastes good. Pork chops taste good.'

Jules suggests that a sewer rat may taste like pumpkin pie but he would never know because 'I ... wouldn't eat the filthy motherfucker.' Further, 'Pigs sleep and root in shit. That's a filthy animal. I don't wanna eat nothin' that ain't got enough sense to disregard its own feces.'

How about a dog? asks Vincent. Don't dogs eat their own shit? Yes, but I don't eat dog either, replies Jules. But is a dog a filthy animal? queries Vincent. Dogs are not filthy but definitely dirty, suggests Jules; in any case a dog has a personality. 'And personality goes a long way.' 'So by that rationale' argues Vincent, 'if a pig had a better personality, he'd cease to be a filthy animal'.

'We'd have to be talkin' about one motherfuckin' charmin' pig', exclaims Jules. 'It'd have to be the Cary Grant of pigs.'

The snake that runs through us like the casing of a sausage - the intestinal tract - is our outsides folded in, where the world out there insistently greets our inner-sense, by-passing the visual and auditory for 
the lower animal senses. The guts have become a celebrated work of art - shortlisted for the 1995 (British) Turner Prize - in Mona Hatoum's endoscopic exploration of her own body, filmed and projected back onto a circular floor area complete with a soundtrack of intestinal gurgling and rushing of fluids. Our delight, intrigue, and surprise at this work occurs precisely because what is normally non-visual and nonauditory is translated into a spectacle for the eyes and ears as it is simultaneously stripped of its taste, smell and touch.

The gut weathers our excesses, and through it rolls our sustenance. From it we get gut responses, the intuition of the entrails, the animal wisdom of the gut feeling; the readiness for action that Nietzsche called 'intestinal fever'. While poking fun at the folk belief, Flaubert, in his lampooning of bourgeois mentality collated as The Dictionary of Received Ideas, reminds us that nightmares 'Come from the stomach'. Nightmares are where the imagination most insistently pathologizes, and the gut, replete with bacteria, is of course, day and night, busy making shit.

The pig, Flaubert reminds us in his The Dictionary of Received Ideas, has insides 'identical with those of a man'. Once, imagining himself inside the body of a pig in a dream, Flaubert finds his pig-nature wallowing in the innards and ejected fluids of human bodies: 'I caught sight of clots of blood... blue intestines ... the vomit of orgies... the greenish pus that runs from wounds', where innards of pig and innards of human begin to be identified as one common sinking and stinking body: 'All this gurgled inside my body' as it also 'lapped against my ears ... I was eating and swallowing it all' (in Mrosovsky, 1983, p. 14). The poet, seeing into the pig with an animalizing eye, invokes the pig's revenge upon the human who would disparage the creature as low and filthy, where pig-nature has burrowed significantly into the psychological innards of the human and has then been everted in a reflex of disgust, so that the human is now endowed with an inside-out perspective and is found wallowing in his own despised interiority and inferiority.

David Farrell Krell (1995, p. 121) cites Kafka's description of vomiting as 'to drag my entire insides to the outside', which Krell sees as 'a phrase that speaks the very dialect of the forest animal', an animal that roots or burrows. Ejection of the gut's contents, analogous to turning the body's interior inside out, is the most basic of human reflexes and the original poetic utterance. Vomiting (as the behavioural aspect to the instinct of distaste or disgust) protects against potential poisoning, where the vomit reflex constitutes the primary act of discrimination and therefore forms the biological basis to aesthetics. As a discriminatory gesture, it is 
an act of purification, or closure, resisting the sublime (which demands a tolerance of sickness).

The anti-hero in Maldoror by Isidore Ducasse (discussed in Chapter 4) dreams that he enters the body of a hog, 'and that I was wallowing in the most foul mires'. The change from human body to pig body is welcomed as 'a perfect and long-awaited happiness' bringing an 'ineffable sensuality'. The description is precise, for a sensuality that cannot be expressed in words restores animal nature, and to the human mind necessarily represents a mystery. For Hillman (1982, p. 288), the pig's 'exaggerated compulsive physicality is the very drive downward into the mystery of life's materiality'.

In The Odyssey, Homer sees the difference between human body and pig body as resting with the magical intervention of the sorceress Circe, who befriends the wildest animals and whose powerful potion turns Odysseus' men into swine - in body only, for, their 'minds were as human as they had been before the change'. In a compact re-telling of this story, the poet Thom Gunn (1979), in 'Moly', sees the 'method' of the human disappear into the 'bulk' of the pig, so that the mind itself becomes 'streaked' like ham or bacon, and adopts, or adapts to, pig needs - a precise poetic image of animal fecundity, of mind descending into matter and recovering the 'ineffable sensuality' described by Ducasse, that is a rich, fatty animal awareness, a new-found sensual pleasure. The animalized mind then adopts the body sense of the creature and enjoys an aggressive sensuality in rooting and burrowing: 'My teeth tear, tear. I am the snouted creature/ That bites through anything, root, wire, or can./ If I was not afraid I'd eat a man.' Like Gunn, Ducasse, in Maldoror, also restores this aggressive sense of animation, where, having become pig, the body wants to not only root but bite: 'I tried out my teeth on the bark of trees; I contemplated my snout with delight'.

In the poem 'Moly' Gunn sees virtue in Odysseus's sailors' entrapment in pig body, as he switches the reader from human perspective to that of the animal: 'Oh a man's flesh already is in mine'. Of the whole crew, it is only Odysseus who resists the magic of Circe, through ingesting the herb Moly, thus repeating the ancient battle not only between masculine hero and moon goddess as sorceress, but also between human heroic will and animal nature represented by the goddess's familiars. The flesh of Odysseus' sailors is however now fully 'buried in swine', fulfilling not only an identity of innards - Pig's with humans; but also an identity of flesh, for human flesh is reputedly said to taste like pork. Again, Odysseus' sailors (as does Maldoror) lose their bodies to regain embodied minds, minds that now can only live through 
immediacy - unmediated perception - in snout awareness. The life of mind is then not separated from sense (the Cartesian fallacy) but recovers a sensual embodiment. Through myth, we have entered the realm of the real.

Thom Gunn's contemporary, the late Ted Hughes, in 'View of a Pig', says of pigs, 'Their bite is worse than a horse's -/ They chop a halfmoon clean out./ They eat cinders, dead cats.' Pigs are like fevered people: 'Pigs must have hot blood, they feel like ovens.' People fevered by hunger (greedily taking half-moon bites out of pork chops) eat like 'pigs'. Robert Grinnell (1973, p. 51) refers to 'food and hunger' as the primary expression of 'the religious instinct', rather than sex or power. (Subsequently reinforced by the current explosion of 'eating disorders', primarily among young women and often associated with self-harming, body image, sexuality, fashion, and consumerism.) What better model for hunger, and then the religious instinct, than the rooting pig, returning us to the fundamental emotions connected with taste, discrimination or the aesthetic instinct: anticipation, surprise, the pleasure of what is good to eat; and disgust exercised in the reflex of rejection, spitting out, vomiting? Through these metaphorical meals of pig flesh and no less through actual ham or bacon - the animal god's body enters our entrails not only for interior pleasure, but also for the pleasure of interiority. Through the meal, we gain an imagination of interiority. And in digesting Homer, Flaubert, and the poets such as Gunn and Hughes, we give body to imagination through sacred meals consisting of gustatory textual images of animals such as pig, developing a taste for the animating imagination, and then for the primacy of aesthetics or the imagination of taste. We should remind ourselves that the root of the word 'aesthetic' means to gasp, with an in-breath, in wonder, surprise or fear; also, to smell and to taste.

\section{Animal beauties}

'There are few things uglier than a lack of reverence for animals' suggested the groundbreaking scholar of Greek religion Jane Harrison (1963, p. 450), in 1911. (Thus implying the reverse: that reverence for animals introduces beauty.) She goes on to suggest that the exclusion of the animal from 'the cycle of the divine... leaves a sense of chill and loneliness', and bemoans the humanizing of the Olympian deities as a move away from the plenitude, colour, form and vitality of animal life to 'the monotonous perfection of the purely human'. Once, Zeus was woodpecker; Athena, owl; Poseidon, horse, and so forth. 
The animal is first and foremost an aesthetic deity: a model for the immediacy of sense as a challenge to the culture's privileging of the abstractions of mind, such as interpretation; for beauty before utility, for the raw before the cooked. The cosmos may then be returned to the metaphor that Plato in Timaeus wished upon it, that the body of the cosmos may be apprehended as a composite beast: 'the animal which was to comprehend all animals' (Plato, in Adler, 1990, p. 449). For Plato, the world is a self-regulating organism: 'a living creature truly endowed with soul and intelligence', again as a composite animal of which 'all other animals ... are portions' (ibid., p. 448). Such a view, contemporary with the Hebraic myth that opens Genesis and predating James Lovelock's 'Gaia' hypothesis by 2350 years, is also in tune with contemporary biology's interest in complexity theory. The 'intelligence' of the creature that is the emergent cosmos and its composite worlds, has, as discussed above, been characterized as the overall (emerging) properties of systems whose maximum efflorescence is always at the edge of chaos, constituting 'laws of complexity' (Kauffman, 1995).

Biologists such as Brian Goodwin (1995) are recapitulating the interests of an earlier generation of morphologists such as Adolf Portmann by attempting to restore interest in questions of how animals and plants come to achieve their forms. This approach refuses to reduce animals for example to chemical/genetic descriptions, and refuses to anthropomorphize animals through metaphors of a militaristic ('camouflage') or utilitarian ('survival') nature. From such a post-modern biology, 'What will emerge is no longer... (an animal) ... struggling for survival, but a rather different type of creature, described by different metaphors' (ibid., p. 39). Goodwin celebrates the animal as a complex aesthetic organism, dynamic and self-organizing, again refusing the metaphors of struggle for survival (competitive individualism) bolstered by laws based on quantities, replacing these with descriptions of the qualities of animals. This approach follows Kant's notion of aesthetics as 'purposiveness without purpose'.

Alphonso Lingis (1983, pp. 8-9), in a discussion of Adolf Portmann's seminal work that demonstrates an aesthetic grounded in biology, points to a relationship between the display of animals and the perception of that display by other animals as a unity, defying functional or operational explanations. Animal display offers ostentation 'over and beyond camouflage and semantic functions'. Display is a 'Glory' and 'spectacle' first, a functional language second. Display is for 'appreciative eyes' and 'It is not surprising that humans... derived their sense of beauty from other animals' (Lingis, 1994b, p. 135). Lingis' Ark, however, 
is elitist - stocked with jaguars, leopards and pumas, from which the drab and slow animal is excluded, mirroring the discriminatory human trope where 'Puma' make running shoes not orthopaedic sandals or wellington boots; and 'Jaguar' do not produce economy hatchbacks for shopping in town or lingering in the slow lane.

While concluding that the 'meaning' the animal brings to the world is primarily aesthetic, let us not limit aesthetic to 'beauty', to high profile or ostentatious animal display; and let us not exclude from the aesthetic the sublime - the terrors of display. We should not exclude from the Ark either the woodlouse because it appears to be lowly, or the alligator because it snaps backbones and rips flesh. Psychological animals also intend the human psyche with differing intensities or levels of desire. Often, the sublime images (such as nightmare animals) make the greatest impact and linger longest, sometimes through a lifetime, and sometimes such images feel the need to recur, to impress themselves through the psyche upon waking or remembering consciousness, over and over. Animal images offer both tolerable and intolerable animal faces, animal postures, animal pelts, their smells and sounds, their atmospheres and presences. And, in the absence of such animality, we miss the beasts and call out for them, as we sense their approach, or feel that they are watching without directly intending, sometimes alone, sometimes in packs. Lacan was right to note that the human subject lives in a state of lack, which produces not only desire, but also paranoia.

To continue with our celebration of animal beauties, echoing Plato's model of the cosmos as a composite animal form, the animal kingdom itself, as a whole, may be imagined as a composite body: a complex, ranging organism showing organization in depth and self display in breadth, a multivariant aesthetic or sensual and sensory presentation of body. Zoologists and natural historians often prefer functional descriptions of animals to the emphasis (and bias) here upon immediacy of presentation demanding appreciation - a biology grounded in aesthetic. Typical of such an instrumental or functional approach is that of Beynus (in Masson and McCarthy, 1996, p. 190) in a natural history book written for the general public. This account resorts to a mixture of utilitarianism and hardheaded sociobiology in a description of the 'purpose' of the peacock's extraordinary display. Beynus asks what it is about the peacock's fan that makes the peahen interested and sexually receptive: 'The iridescence? The graceful shape? The spots that look like eyes?' None of these aesthetic features suggests the author, rather it is merely 'the sheer size of the fan', that itself signals something about the health of the bird carrying it. To carry such a fan, the adult male 'must 
be both strong and wily'. Further, the female may not be drawn to the colour of the plumage, but to the fact that the 'sheen shows that the bird is free from parasites'. Then females are 'rewarded by passing on their genes' through healthier offspring.

In Beynus's functionalist reading, first the peacock displays quantity not quality (a variant on our current obsession in the Information Age with raw quantity of information rather than imagination of such information). Second, following sociobiological orthodoxy, this secures a 'future' for the 'selfish' genes. Effectively, the magnificent display of this extraordinary beast is merely a receptacle for its guaranteed continuity - the safety of the genes. The aesthetic appreciation of the animal is then squashed, displaced by the utilitarian. Jeffrey Masson and Susan McCarthy (ibid.) offer derisive comment on this same passage, suggesting that the peahen may not be 'thought of as a calculating gene-shipper', but may find the peacock's tail simply beautiful in its own right, as we do. Why ignore the self-evident? - the peacock's tail is beautiful in its surplus, its swagger, and its wanton exaggeration (as is the rest of its plumage). Beynus's reading is also Puritan, mean-spirited, resisting the model of biological life proposed by Georges Bataille (1991), based on the value of excess. Following Marcel Mauss's description of the potlatch ceremony of Pacific Coast Amerindians, where surplus is not hoarded or re-invested as in Capitalism, but is bound to be given over as a gift, Bataille describes Nature as overabundant, working on surplus, or offering the free gift of abundant life through the fount of the sun's light, that also paradoxically marks the star's slow suicide or sacrifice. (Although the obligation to give more than one receives introduces certain complex anxieties into human relations - the 'gift' is also an 'accursed share' as Bataille notes in the title to his text.)

Zoologists who are interested in animal beauty, such as Susan McCarthy, above, still however fall into a disguised anthropocentrism. This is to project or displace the Cartesian-Kantian human 'subject' onto the animal as if it were a subject whose interior life might match that of humans in mild representation. Masson and McCarthy describe the 'emotional lives of animals' with great sensitivity for the animal Other, but always through the assumed transcendental ground of a transparent human subjectivity that is necessarily then projected onto the animals despite constant injunctions in their text against the supposed anthropocentrisms and anthropomorphisms of other writers and commentators. Many writers on animal 'experiences', while intentionally of a broad animal rights persuasion, reinforce this human-centred fallacy because they have not first established a critical perspective towards 
what they regard as human or anthropological experience, specifically human subjectivities.

There is a dual process at work. 'Animal', set up as 'Other' through exclusion of whatever poisons the purity of the category 'human', comes to define the human. However, the human is also defined by what it includes, and this will involve a sense of animality, recovered from the animal world. As we ship this back to the category 'human', we want to limit it, qualify it, not shipping back a 'bestiality'. Hence, we want animals to have human-like experiences and consciousness, so that we can include them as a defining feature of the human psyche. This process may be further grounded in, and made more complex by, the tendency to confuse the presentational event with the representational experience and recounting of that event. What if we were to switch focus from the inner life of the experiencer (animal or human) to the event experienced (animal or human display, set among a world in display)? This switch from presentation (the event itself) to representation (the event as experienced and recalled) reminds us that we might 'see' the self-displaying peacock in its own right as offering beauty.

Of course, in a post-Kantian world of the crisis of representation, objections will be readily raised to this position. In the Kantian tradition, unmediated 'immediacy' of perception is impossible, as the world of objects is mediated, represented through transcendental human categories of space, time, causality and morality. 'Reality' or 'Nature' is always a construction. Schools of direct and indirect realism, where varying degrees of unmediated perception are recognized, and where it is noted that the environment intends us, or educates our attention, counter such an idealism. In such views (Adolf Portmann, James Gibson, James Hillman), what is often implied is that states of unmediated 'immediacy' are facilitated by an 'animalizing' of the human psyche, as a prepresentational state. This switch from idealism to indirect realism would celebrate display for its own sake, as Adolf Portmann celebrates the bird song that is 'free' or not tied to 'function'. Also, it would switch attention to the act and away from the experience of the act, so that singing for the bird is now for the sake of the song, and neither for the bird itself nor the listener. It is the song's individuation which now becomes central, supporting the view of the biological world as a selfgenerating, intelligent, deeply organized system concerned with emergence out of surplus - a system with 'time' on its hands whose purpose is primarily aesthetic: a purposiveness without functional purpose. 